\title{
II.-ON a Collection of Trilobites from the Upper Cambrian of Shantung, North China.
}

\author{
By Hexir Woodward, LL.D., F.R.S., F.G.S. \\ (Conchded from the llay Nimber, p. 215.)
}

\section{(PLATE XIII.)}

ConTinuing the notice of Herr H. Monke's paper on the $\bigcup$ Trilobite-bearing limestone slabs of Yen-tsy-yai, the author observes : - The very dense and solid, slightly arenaceous lime-

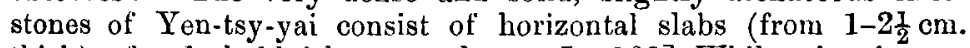
thick) of a dark bluish-grey colour. [p. 109] Whilst showing no. traces of fossils in their interior, the limestone slabs are on one side (as shown on $\mathrm{pl}$. ix) ${ }^{2}$ often completely covered with the remains of Trilobite carapaces, besides which are found only isolated very minute shells of Brachiopoda. Between them are here and there irregular, lengthened furrows, which may be the tracks of the Trilobites; on the corresponding opposite parts of the slabs are similarly shaped vermiform protuberances. It follows that the fossiliferous side is to be considered as the natural upper part of the slabs. In a certain number of the slabs either both sides or one only are covered besides by a thin argillaceous stratum, which equally contains, though less frequently, delicate remains of fossils: in all the other slabs the fossils present themselves en relief and often rest on a small base of limestone, and therefore convey the impression of having been originally covered by a thin argillaceous stratum, which later on was washed away by water.

Where the fussils are covered by the protective argillaceons layer and could be developed by preparation, they are in an excellent state of preservation; where, however, the argillaceous layer is wanting, the fossils are generally much worn and their delicate sculpturing has disappeared. Complete carapaces of Trilobites have not been found; with the exception of a single instance in which seven pleura are still united in their original connection, all the carapaces were broken up into single segments; these present themselves mixed together, exhibiting either their superior or inferior side on the upper surface, and are much broken. This condition of things makes it, of course, difficult to find out the parts which belong together; on the other hand, it enables one to study the structure of the carapace in all its details. A close examination revealed the remarkable fact that the remains do not belong solely [p. 110] to adult specimens, but that every possible degree of age, down to individuals of microscopic size, are present in about equal numbers. The explanation of this phenomenon may be that the thin

1 Our Plate XIII is not copied from Herr H. Monke's beautiful plate, but is taken from a part of the fine slab presented to the British Museum by the Rev. Samuel Couling, II.A., Ching-chow-fu, Kiao-chow, China, and was evidently obtained from the very same quarry which furnished the slabs forwarded to Berlin by Herr Bergmeister F. Koerfer, from the Upper Sinic Limestones of Yen-tsy-yai, where a considerable trade in these slabs, crowded with remains of Trilobites, appears to be carried on by the Chinese, under the title of "petrified swallows ' ! 
argillaceous layers between the single limestone strata correspond to periods during which the conveyance of fine argillaceous sediments produced a widespread turbidity of the water, so that the Trilobites could take advantage of these periods to undergo their ecdysis whilst protected from the eyes of their enemies.

What besides makes these slabs from Yen-tsy-yai particularly interesting is their surprising agreement with the above-mentioned plate from Peking, as the comparison of our pl. ix with Bergeron's pl. xiii will show; so that the latter might be presumed to come from the same locality (as already mentioned, these slabs are commercial artioles in China). ${ }^{1}$ However, a closer investigation shows small differences in the fauna, and for this reason I incline to admit that the slab in fact comes "from the mountains north of Peking," where, according to Von Richthofen (op. cit., p. 317), the Sinic strata are abundantly represented in the Nankón chain. There is no doubt that this slab belongs to the same, or approximately the same, geological horizon as those from Yen-tsy-yai. Regarding the other question, whether all the 73 slabs from the latter locality are of the same geological horizon, it may be mentioned here, in anticipation, that almost without exception each of the slabs exhibits representatives of all the species of Trilobites named in the collection, save in the case of some of the rarer forms.

In the memoir by Herr H. Monke, from which we have extracted the foregoing account of the Trilobite-bearing beds of Yen-tsy-yai, the author figures and enumerates the following genera and species, namely :-

1. Agnostus Koerferi, gen. et sp. nov., taf. 3, figs. 1-9.

2. Liostracina Krauseri, gen. et sp. nov., taf. 3, figs. 10-17.

3. Teinistion Lausi, gen. et sp. nov., taf. 4, figs. 1-17.

4. Teinistion Sodeni, gen. et sp. nov., taf. 5, figs. 1-4.

5. Drepanura Premesnili, Bergeron, taf. 5, figs. 5-19.

6. Drepanura Ketteleri, sp. nov., taf. 6, figs. 1-14.

Embryonal forms, taf. 6 , figs. 15-18.

7. Stephanocare Richthofeni, gen. et sp. nov., taf. 7, figs. 1-15.

8. [Stephanocare sinense, Bergeron (not figured).]

9. Stephanocare, sp., taf. 8, figs. 1-4.

Drepanura Ketteleri (hypostome), figs. 5-6.

Drepanura Premesnili (hypostome), Bergeron, taf. 8, figs. 7-9.

Stephanocare Richthofeni (hypostome), taf. 8, figs. 10-11.

Slab (taf. 9). This slab, which agrees most exactly (even in size) with that of which a part forms the subject of our Plate XIII,

1 This seems less surprising when it is borne in mind that the higher classes in China are very great connoisseurs of natural curiosities, which they purchase and cause to be mounted as articles of bijouterie and vertu. Natural stones of all kinds cut and squared up or cut and polished are sold in the shops of cities in China, often long distances from the localities where the specimens were originally obtained. Mr. Crick has referred to this circumstance in connection with the celebrated 'pagoda-stones' (sections of $O_{r}$ thoceras), which, being cut into slabs and mounted in frames to form ornamental pauels and screens, may now be met with as trade articles in almost any part of China.--H. W. 
contains abundant representatives of parts of all the species of Trilobites enumerated above, except Stephanocare sinense of Bergeron. It measures $245 \times 205 \mathrm{~mm}$.

The slab obtained by the Rev. S. Couling also measures $250 \times$ $205 \mathrm{~mm}$., but the portion photographed and figured only represents about $180 \times 112 \mathrm{~mm}$. In order to add to the value of the slab an additional tail of Drepanura Premesnili, Bergeron (Fig. 1), has been very carefully inserted by the Chinese lapidary into the slab (see Plate XIII, $3^{*}$ ), though its identity as a species which occurs in this bed from Yen-tsy-yai is vouched for by other pygidia of the same species forming a part of the original slab.

In the form named Drepanura Ketteleri, H. Monke (which like Drepanura Premesnili, Bergeron, is founded upon detached pygidia and separate and imperfect head-shields, also with elongated cheekspines), the Jateral caudal spines are very much more elongated, and remind one of the very long lateral cheek and caudal spines of Bathynotus holopyga, Hall, from the Lower Cambrian (or Olenellus zone of Walcott), Western Vermont, North America. [Fauna of the Lower Cambrian, C. D. Walcott, pl. xcv, figs. 1, 1a, p. 646.]

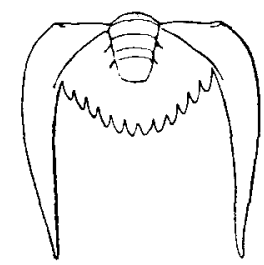

Fis. 1.-Tygilium of Drepanura Premesnili, Bergeron. Nat. size. N. Cambrian: ren-tsy-yai, Prorince of Shantung, North China.

Stephanocare Richthofeni, of which detached parts are seen upon our slab, Pl. XIII, Figs. 1 and '2, is represented on Herr Monke's plate by six glabellæ, two detached free-cheeks, and three pygidia. There is an element of uncertainty about the correlation of some of these, the underside of the pygidium (figs. 12 and 13) not agreeing very well with the upper side (fig. 11, taf. 7), nor the glabella (figs. 1,2, and 3) with tigs. 4, 5, and 6 of the same plate (taf. 7 ).

I figure, p. 254 (Fig. 2), a detached pygidium preserved on a piece of yellow, compact, fine-grained limestone, which has been polished probably carefully and constantly by hand until it resembles a piece of polished 'Boapstone.' It is near to Herr Monke's fig. 11, taf. 7, but either his specimen is unsymmetrical (a very rare occurrence in a Trilobite), or else the artist has drawn the pygidium with six marginal dentations on the left side of the figure and seven on the right, or he intended to indicate that it had one central spine and six marginal spines on each side. In fig. 12, depicting the underside, the artist represents it with six dentations on each side and no central spine. The number of coalesced segments in Herr Monke's fig. 11 is four; in Mr. Couling's specimen, drawn p. 254 (Fig. 2), there are six coalesced segments visible and a small mucro in the centre 


\section{Dr. H. Woodward-Trilobites from Shantung, N. China.}

with six clearly defined marginal serrations on each side. For this form of pygidium Bergeron ${ }^{1}$ adopts Meek's generic name Olenoides, ${ }^{2}$ with which it certainly agrees most closely. I should venture to suggest to Herr Monke that Stephanocare should be merged in - Olenoides (Meek, 1888) as the older and established name.

The specimen here referred to Fig. 2 (locality uncertain, probably from Shantung) measures $31 \mathrm{~mm}$. in breadth, by $19 \mathrm{~mm}$. in length; the axis is $16 \mathrm{~mm}$. broad at the proximal border, where it once joined the cephalothorax, diminishing gradually to $6 \mathrm{~mm}$. above, where it terminates in a slender, rounded, mucronate point, which merges distally into the dentated border. The pleuræ or lateral lobes of the tail are roundly elevated and elegantly curved, as shown in the two views ( $a$ and $b$, Fig. 2). They are covered with minute rounded pustules. A shallow groove divides each lobe or coalesced segment of the tail by a smooth and well-marked furrow. The divisions of the axis are rounded and raised, and separated by well-defined grooves.
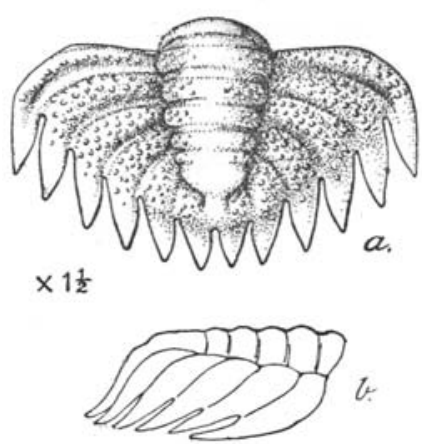

Frg. 2.-Olenoides Richthofeni? (Monke), sp. Upper Cambrian (?): Shantung, North China.

It is interesting to notice how closely this form (Fig. 2) agrees with the pygidium of Olenoides Marcoui, Whitfield, sp., from the Lower Cambrian of North America (see Walcott, Fauna of Lower Cambrian, pl. xciv, figs. $2 a, 2 b$, pp. 642 and 575). It also agrees closely with Bergeron's figures and those of Herr Monke's (taf. 7, figs. 11, 12, and 13). Several other pygidia occur on smaller slabs of yellow limestone, obtained by the Rev. S. Couling at Kiao-chow, North China, though not from Yen-tsy-yai, but one of the other fossil-yielding quarries in the Shantung province. ${ }^{3}$ There are also some additional Cephalopods which it is hoped may yield further information as to the age of these beds when Mr. G. C. Crick is enabled again to take them up.

It would be very agreeable to review in detail Herr Monke's

1 "Etude de quelques Trilobites de Chine": Bull. Soc. Géol. France, sér. III (1899), p. 499 , t. 27 .

2 American Journal of Science, ser. IIT (1888), vol. xxxvi, p. 165.

3 They are probably identical with Bergeron's Olenoides Leblanci, op. cit., p. 506, fig. 5 , also seen on slab, pl. xiii, fig. 5 . 


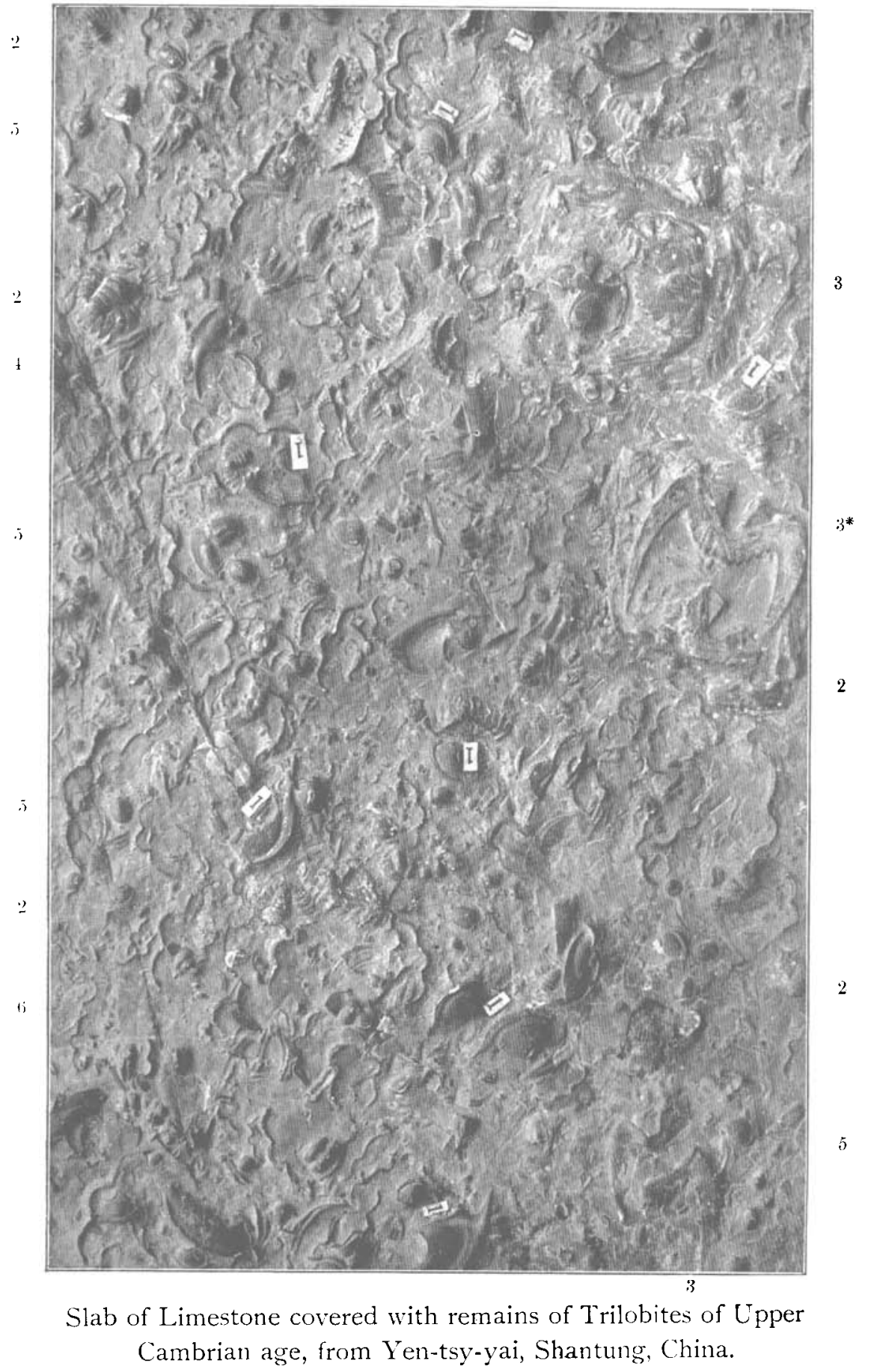


species from North China, but I feel before doing so the need of better and more complete specimens at my command upon which to found a revision. I can, therefore, only express my thanks to Herr Monke for the valuable work he has accomplished with the very fragmentary material at his command. I have also to tender my best thanks to the Rev. Samuel Couling for entrusting me with all the specimens he was able to obtain and presenting them to the Geological Department of the British Museum (Natural History), Cromwell Road.

\section{EXPLANATION OF PLATE XIII.}

The photo reproduction of fossil remains shown on our plate has been taken from a portion of a large slab procured by the Rev. Samuel Couling, M.A., of Kiao-chow, North China, and in age considered by Herr H. Monke to be Upper Cambrian. The slab and its trilobites agree exactly with a number of others obtained for the Royal Prussian Geological Survey and Berg-Akademie in Berlin from Yen-tsy-yai, in the Province of Shantung, North China. Size of original slab, $250 \times 205 \mathrm{~mm}$. Size of portion of slab reproduced in plate, $180 \times 112 \mathrm{~mm}$. On the slab may be seen examples of the following genera and species, indicated by small figures on the margin of the plate, and in the case of Fig. 1 on the fossil slab itself :-

Frg. 1.-Free-cheeks of Stephanocare Richthofeni (very numerous).

"2.-Py'gidia of Stephanocare Richthofeni (seven examples).

", 3.-Pygidia of Drepanura Premesnili, Berg. (five examples).

", 4.-Free-cheek with cheek-spine of Drepanira Ketteleri (one example).

", 5.-Head-shields and pygidia of Agnostus Koerferi (numerous).

", 6.-Hypostome of Stephanocare Richthofeni (one example).

This slab, together with various other separate Trilobite remains and some Cephalopods, have been presented by the Rev. Samuel Couling, M.A., to the Trustees of the British Museum (Natural History) for the Geological Department.

\section{III.-Note on Fragments of Chert from North China.}

By Dr. George J. Hinde, F.R.S., F.G.S.

TIEE fragments of partially weathered chert from North China 1 sent by the Rev. S. Couling, ${ }^{1}$ unfortunately without indication of the particular locality or formation where they were collected, are of whitish, slate-grey, or pinkish aspect, and in two instances show traces of banded structure. They consist of cryptocrystalline or microcrystalline silica with small areas in which the silica is of a fibrous chalcedonic character. Remains of organisms can be distinguished in each of the four microseopic sections which have been prepared, but they are generally so shadowy and indefinite that their nature cannot be satisfactorily determined. Some portions of slide marked A are crowded with slender, straight, or slightly curved linear bodies, about $11 \mathrm{~mm}$. in length by $01 \mathrm{~mm}$. in width, which in places have a sub-parallel or sheaf-like arrangement. They might be supposed to be sponge spicules, but in their size and disposition they seem to differ from any fossil spicules with which I am acquainted. Slide $\mathrm{C}$ largely consists of numerous small, rounded, oval, and conical forms without walls, ranging from $\cdot 1$ to $1.7 \mathrm{~mm}$. in diameter. In outline and in size many of these

1 Of Ching-chow-ín, Kiao-chow, Shantung, North China. 